\section{Tumor-Infiltrating Macrophage and Microvessel Density in Oral Squamous Cell Carcinoma}

Deise Souza Vilas Bôas ${ }^{1,2}$, Christina Maeda Takiya², Clarissa Araújo Silva

Gurgel $^{3,4}$, Márcia Grillo Cabral ${ }^{5}$, Jean Nunes dos Santos ${ }^{3,4}$

\author{
'Department of Biomorphology, \\ Institute of Health Sciences, \\ UFBA - Federal University of \\ Bahia, Salvador, BA Brazil \\ ${ }^{2}$ Laboratory of Cell Pathology, \\ Institute of Biomedical Sciences, \\ UFRJ - Federal University of Rio de \\ Janeiro, Rio de Janeiro, RJ, Brazil \\ ${ }^{3}$ Graduate Program in Human \\ Pathology, F10CRUZ - Oswaldo Cruz \\ Foundation, Salvador, BA, Brazil \\ ${ }^{4}$ Laboratory of Oral Surgical \\ Pathology, School of Dentistry, \\ UFBA - Federal University of \\ Bahia, Salvador, BA, Brazil \\ ${ }^{5}$ Department of Pathology and \\ Oral Diagnosis, School of Dentistry, \\ UFRJ - Federal University of Rio de \\ Janeiro, Rio de Janeiro, RJ, Brazil
}

Correspondence: Prof. Dr. Jean Nunes dos Santos, Avenida Araújo Pinho, 62, Canela, 40110-150 Salvador, BA, Brasil. Tel: +55-71-32839019. e-mail: jeanunes@ufba.br

Key Words: angiogenesis, macrophages, oral squamous cell carcinoma, immunohistochemistry.

\section{Introduction}

The growth of oral squamous cell carcinoma (OSCC) occurs mainly as a result of the proliferation of malignant cells and the formation of supportive tissues such as new blood vessels. Due to this occurrence, a larger angiogenesis in OSCC is commonly associated with a more aggressive behavior of the tumor and a poor prognosis (1). In addition to blood vessel, the tumor microenvironment contains cells and chemical mediators that have also been the focus of studies due to their capacity of predisposing to tumor development and its dissemination (2-4).

Both physiological and pathological angiogeneses are characterized by the sprouting of new blood vessels from extensions of the existing vasculature mediated by the balance between proangiogenic and antiangiogenic factors. This regulation involves the interaction between endothelial cells, smooth muscle cells and pericytes, in addition to various stromal components that play an important role in the angiogenic process (5). In tumors, angiogenesisregulating molecules are produced and disseminated mainly by the neoplastic cells themselves and by leukocytes, mast cells, fibroblasts or macrophages found in proximity to the tumor $(3,6,7)$. Currently, anti-angiogenic therapy can influence the management of many tumors by different mechanisms (8).

Tumor-associated macrophages (TAM) are the main cellular component in the stroma of many tumors (3). Although macrophages can serve as negative or positive regulators of tumor growth $(3,9)$, they have been the focus of studies due to their functions performed on behalf of the tumor, including the expression of growth factors and metalloproteinases, suppression of adaptive immunity and promotion of angiogenesis $(3,9,10)$, demonstrating their importance for tumor progression. TAM are able to induce the formation of new blood vessels through the expression of potent proangiogenic molecules, including vascular endothelial growth factor (VEGF), platelet-derived growth factor (PDGF), transforming growth factor beta (TGF $\beta$ ) and angiogenic chemokines such as monocyte chemotactic protein-1 (CCL2/MCP-1), whose levels are associated with the accumulation of TAM $(3,10)$. In addition, TAM exert mobilization of angiogenic growth factors embedded in the extracellular matrix and interact with endothelial cells to improve blood vessel growth (4).

It is known that tumor microenvironment plays a key role in the tumor progression, including OSCC (11-13). Nevertheless, there are few studies focusing on angiogenesis and TAM regarding this cancer. Thus, the aim of the present study was to assess the microvascular density (MVD) and infiltrating macrophage density (IMD) at different histological grades of OSCC.

\section{Material and Methods Tissue Samples}

After approval of the study by the Ethics Committee, OSCC biopsies from 25 patients were selected. The 
anatomopathological records and clinical charts were obtained from the archives of two Surgical Pathology Services (Dental School, Federal University of Bahia and Dental School, Federal University of Rio de Janeiro). None of the patients had undergone chemo- or radiotherapy. After staining with hematoxylin-eosin, the material was reviewed by an experienced pathologist in order to classify the cases according to the World Health Organization International Histological Classification of Tumors (14).

\section{Immunohistochemistry}

Formalin-fixed and paraffin-embedded material was cut into 3- $\mu \mathrm{m}$ thick sections, deparaffinized in xylene and rehydrated in ethanol and water. For antigen retrieval, tissue sections were boiled in citrate buffer, $\mathrm{pH}$ 6.0, for 40 $\min$ in a water bath at $95-97^{\circ} \mathrm{C}$. For immunohistochemical detection, antibodies to von Willebrand factor (Dako A/S, Copenhagen, Denmark; dilution 1:200) and CD68 (clone KP1; Dako A/S; dilution 1:100) were applied overnight using the EnVision ${ }^{\mathrm{TM}}$ System (Dako Corporation, Carpinteria, CA, USA). The immunohistochemical reactions were developed with diaminobenzidine (Dako Corporation) as chromogens to visualize the peroxidase activity and slides were counterstained with Harris hematoxylin.

\section{Microvascular Density and Infiltrating Macrophage Density}

For the analysis of immunostaining, the slides were examined and photographed using a Nikon microscope (Eclipse E800; Nikon, Tokyo, Japan). The observation was blind with respect to the clinical and histological outcomes. For the MVD, von Willebrand factor-positive staining microvessels were counted. The slides were first examined at low magnification (100x) for identification of highly vascularized areas (hot spots). Finally, images of 10 hot spots were acquired at $400 x$ magnification and the MVD was calculated by counting the average number of microvessels in 10 fields (15) with tissue area measured in $\mathrm{mm}^{2}$. Any positively stained individual endothelial cell or endothelial cell cluster that was clearly separate from adjacent microvessels, tumor cells or other connective tissue elements was considered as a countable microvessel. The presence of a lumen was not necessarily required for microvessel counting and large vessels with a muscle wall or a lumen larger than $50 \mu \mathrm{m}$ were excluded (16). For the IMD, CD68-positive cells were defined as macrophages and analyzed as described by Ueno et al. (2). This method consists of quantifying positively stained cells by examination of the five most confluent fields (hot spots). Next, the mean of the three largest counts obtained for the five fields was calculated and the IMD was reported per tissue $\mathrm{mm}^{2}$.

\section{Statistical Analysis}

Differences between groups were evaluated by one-way ANOVA followed by Newman-Keuls multiple-comparison test. The correlation between MVD and IMD was analyzed using the Pearson's correlation coefficient. A $p<0.05$ value was considered to be statistically significant. The GraphPad Prism software, version 4.0 (GraphPad Software, Inc., San Diego, CA, USA) was applied for statistical calculation.

\section{Results}

The clinicopathological characterization of the OSCC tumors is shown in Table 1.

The mean MVD in the tumors was 48.38 microvessels/ $\mathrm{mm}^{2}$ (Fig. 1A-C). Comparison among tumors showed low vascularity in well-differentiated OSCC compared with moderately and poorly differentiated carcinomas (Table 2). CD68-positive cells were observed in all tumors. The mean IMD in the tumors was 91.47 cells $/ \mathrm{mm}^{2}$. These cells were present as clusters or distributed along the inflammatory

Table 1. Clinicopathological characterization of the oral squamous cell carcinoma (OSCC)

\begin{tabular}{|c|c|}
\hline Clinical variable & oscc \\
\hline Age & $\%(n)$ \\
\hline$<60$ & $52(13)$ \\
\hline$\geq 60$ & $44(11)$ \\
\hline Unknown & $4(1)$ \\
\hline \multicolumn{2}{|l|}{ Sex } \\
\hline Female & $40(10)$ \\
\hline Male & $60(15)$ \\
\hline \multicolumn{2}{|l|}{ Tumor site } \\
\hline Tongue & $28(7)$ \\
\hline Floor of mouth & $16(4)$ \\
\hline Vestibule of the mouth & $16(4)$ \\
\hline Buccal mucosa & $12(3)$ \\
\hline Gingiva & $12(3)$ \\
\hline Hard palate & $8(2)$ \\
\hline Retromolar area & $4(1)$ \\
\hline Unknown & $4(1)$ \\
\hline \multicolumn{2}{|l|}{ Histologic tumor grading ${ }^{\mathrm{a}}$} \\
\hline Well differentiated & $40(10)$ \\
\hline Moderately differentiated & $36(9)$ \\
\hline Poorly differentiated & $24(6)$ \\
\hline
\end{tabular}

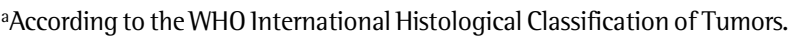


infiltrate OSCC (Fig. 1D-F). The IMD was similar in all groups (Table 2). Pearson's correlation test revealed no significant correlation between MVD and IMD regarding both markers $(p=0.870)$.
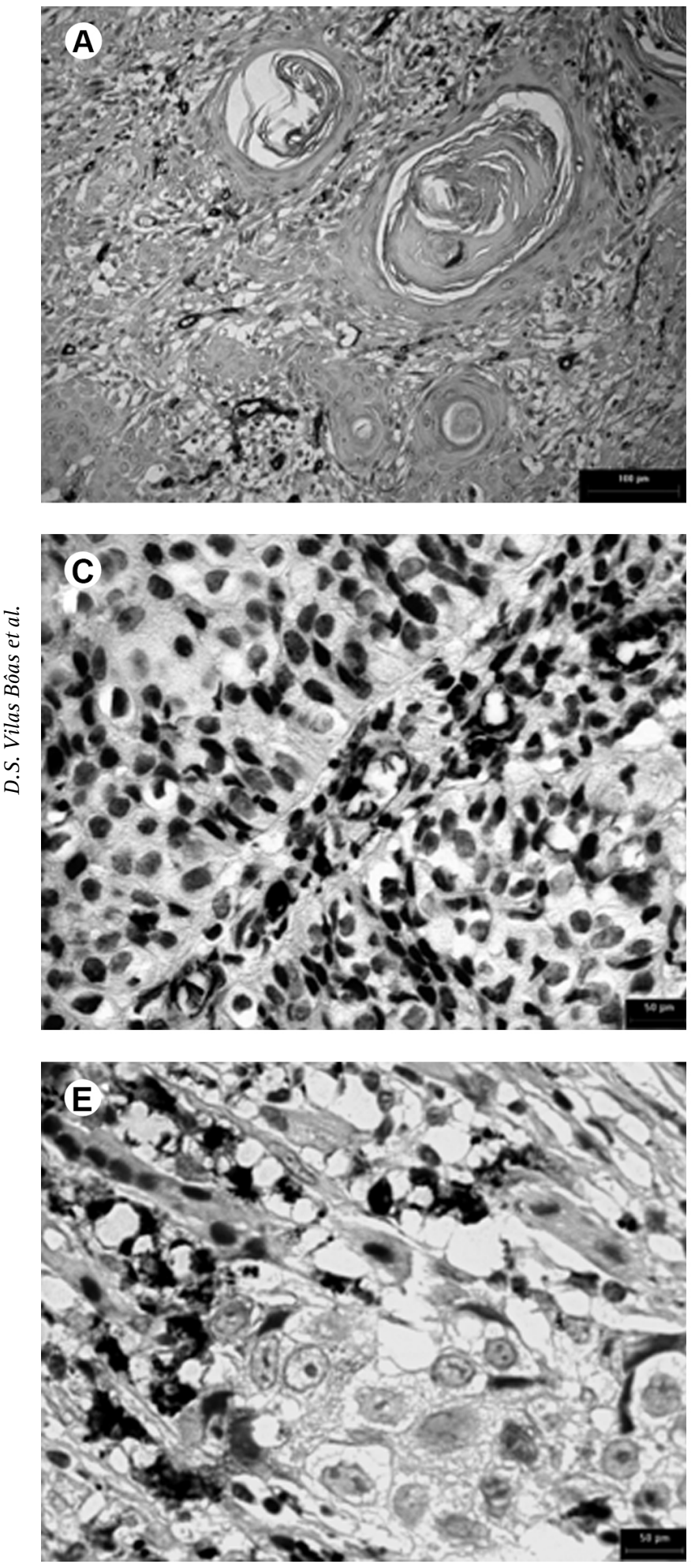

\section{Discussion}

In the present study, the von Willebrand factor (vWf) was used as an endothelial cell marker. This protein is synthesized by endothelial cells and plays an important
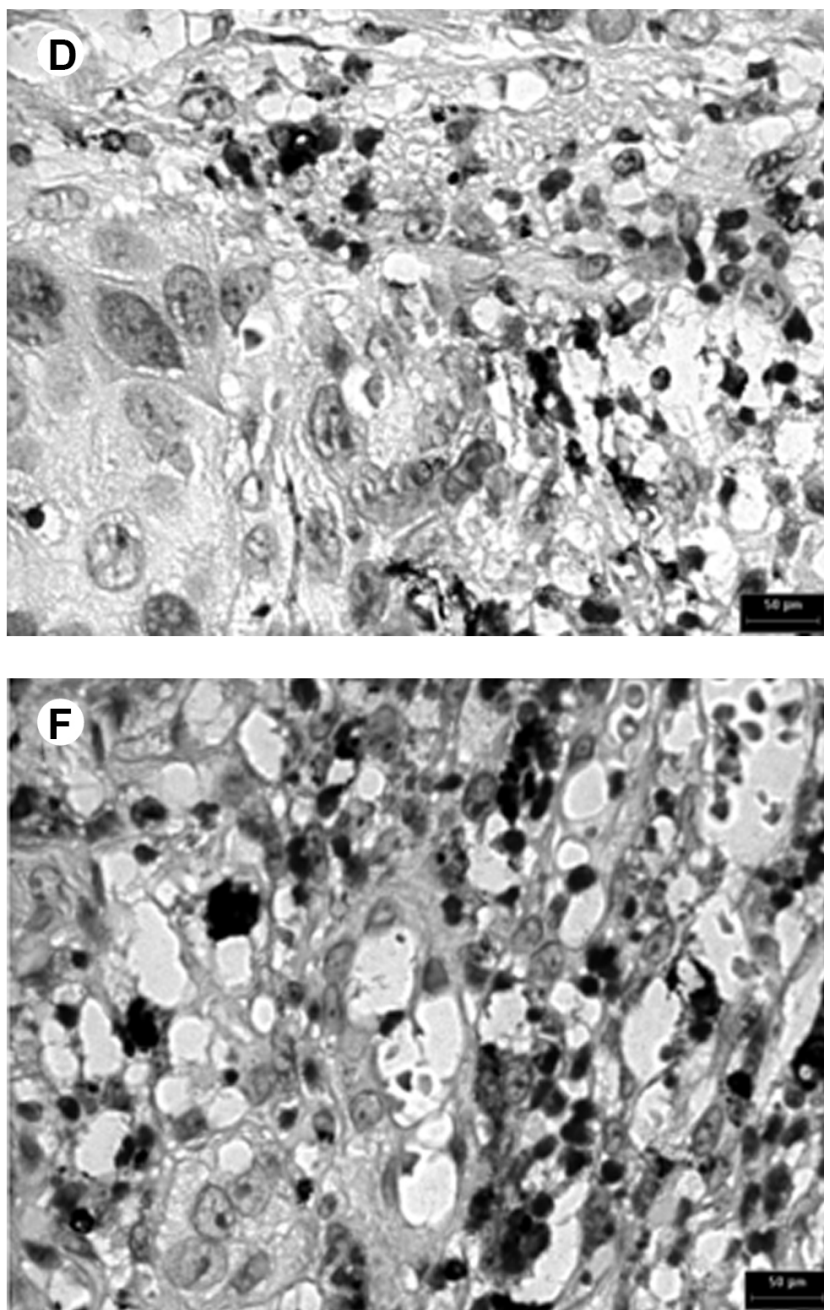

Figure 1. Distribution of tumor microvessels and CD68-positive macrophages in the investigated tumors. Tumor microvessels in a well-differentiated (A, B) and a moderately differentiated (C) oral squamous cell carcinoma (OSCC). CD68-positive macrophages in a well-differentiated (D), a moderately differentiated (E) and a poorly differentiated (F) OSCC. 
role in hemostasis, promoting the adhesion of the first platelets to the vascular subendothelium (17). This fact permits the interpretation of $\mathrm{vWf}$ as an angiogenesis marker $(16,18,19)$. In addition, many investigators strongly advocate MVD as an important factor for establishing the prognosis of different cancers such as breast cancer (18) and oral cancer $(16,19,20)$.

The findings of the present study were similar to those reported by Sharma et al. (19), who found significantly higher MVD in moderately differentiated OSCC than in well differentiated OSCC. This might contribute to the OSCC prognosis, as this lesion may be related to the degree of tumor vascularization $(1,16)$. In this respect, an increase of angiogenesis in patients with OSCC may be related to high levels of interleukin-10 (IL-10), a regulatory molecule for angiogenesis in various cancers that leads to suppression of the immune response in patients (21).

Although the present results showed differences in MVD according to the degree of tumor differentiation, the literature has not yet reached a consensus regarding the influence of angiogenesis on the rate of recurrence, tumor invasion and regional metastasis. Fernandez et al. (22) investigated angiogenesis in OSCC of the tongue and found no evidence that tumor vascularization can be used as an independent factor to evaluate the possibility of recurrence or patient survival. In a similar study, Guttman et al. (16) found a significant correlation between an increased number of microvessels and tumor invasion to the adjacent musculature and lymph node metastasis. Shpitzer et al. (1) counted vessels in OSCC of the tongue and established a positive correlation with the presence of metastases, indicating angiogenesis to be an independent factor for the prediction of lymph node metastasis and for the decision-making regarding the therapy to be used. According to these authors, patients with no clinical signs of lymph node involvement who present high vascularization rates should be submitted to adjuvant therapy and not only to surgical resection.

In addition to blood vessels, solid tumors contain a stromal cellular component that basically consists of fibroblasts and immunocompetent cells, especially macrophages and lymphocytes (3). However, the biological significance of the presence of macrophages has not been completely established, mainly because these cells often have contradictory functions, exerting pro and antitumor actions, depending on their polarization to a M1 or M2 macrophage. Thus, TAM have been described as M2polarized macrophages exhibiting a protumoral phenotype (3). In addition, diverse studies report their influence on angiogenesis and lymphangiogenesis $(4,7)$

TAM are recruited as monocytes from blood in the direction of the tumor by molecules secreted by both malignant and stromal cells in tumors, including VEGF, colony stimulating factor-1 (CSF-1) and chemokines such as CCL2/MCP-1, placental growth factor (PIGF, PGF), macrophage inflammatory protein-1 $\alpha$ (CCL3/MIP-1 $\alpha$ ), macrophage inflammatory protein- $1 \beta$ (CCL4/MIP-1 $\beta$ ) and regulated on activation normal T-cell expressed and secreted (CCL5/RANTES) $(3,10)$. Within the tumor, these macrophages undergo marked phenotypic change and express numerous chemokines and angiogenesis/ lymphangiogenesis-promoting factors that contribute to the onset of tumorigenesis and metastasis, such as VEGF, TGF- $\beta$, PDGF, IL-8, IL-10, prostanoids, reactive oxygen species, in addition to enzymes related to the degradation of extracellular matrix $(3,10)$.

A high frequency of macrophages as observed in the present investigation has also been reported in other studies and has been correlated with a poor prognosis in OSCC $(11,12)$. Despite this aspect, a relationship between increased MVD and the presence of macrophages has been demonstrated in previous studies performed in different types of cancer $(2,7,11,20,23)$. In contrast, in the present study, no correlation could be established between IMD and MVD. These results partially disagree with those reported by El-Rouby (20), who observed an association between an increase in the number of TAM and increased angiogenesis in oral verrucous cell carcinomas and OSCC, although, similarly to ours results, with no significant difference in the area percentage of TAM among different histological

Table 2. Association between microvessel density and infiltrating macrophage density in relation to the histological tumor grading

\begin{tabular}{|c|c|c|c|c|}
\hline Density & $\begin{array}{c}\text { Well } \\
\text { differentiated OSCC } \\
(n=10)\end{array}$ & $\begin{array}{c}\text { Moderately } \\
\text { differentiated OSCC } \\
\qquad(\mathrm{n}=9)\end{array}$ & $\begin{array}{l}\text { Poorly differentiated } \\
\text { OSCC } \\
(n=6)\end{array}$ & $p$-value ${ }^{a}$ \\
\hline Microvascular density & $40.34 \pm 9.10^{b}$ & $56.52 \pm 12.72^{b}$ & $51.45 \pm 19.59$ & 0.046 \\
\hline Infiltrating macrophage density & $83.75 \pm 32.24$ & $88.23 \pm 27.70$ & $106.6 \pm 34.39$ & 0.381 \\
\hline
\end{tabular}

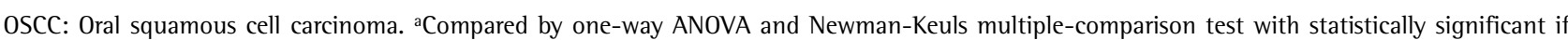
$p<0.05$. Values are shown as the mean \pm standard deviation. 
grades of OSCC.

In this study, there was no significant difference in IMD between the OSCCs with different histological grades. A possible explanation could be the use of $\mathrm{CD} 68$, a panmacrophage marker that does not distinguish the presence of M2-polarized macrophages that are much more relevant for an immunosuppressive cancer microenvironment and its progression (24). Similarly, no correlation was found between IMD and MDV. It is important to highlight that the potential to induce angiogenesis in OSCC is related not only to macrophages, but also other stromal cells as fibroblasts, mast cells and tumor epithelium (19).

In conclusion, angiogenesis and TAM play a key role in different histological grades of OSCC. There was a significant difference between well differentiated and moderately differentiated tumors regarding angiogenesis, which could indicate their influence in OSCC. However, the lack of correlation between MVD and IMD could suggest that angiogenesis does not depend on the number of macrophages present in OSCC, but their predominant phenotype. Further studies involving distinct phenotypes of macrophages should be performed for better understanding influence of TAM on tumor angiogenesis.

\section{Resumo}

Macrófagos associados a tumores (MAT) representam o componente principal do estroma de muitos tumores, além de participar da angiogênese tumoral. Este estudo comparou a microdensidade vascular (MDV) e densidade de macrófagos infiltrando o tumor (DMIT) em carcinoma escamocelular da boca (CEC) com diferentes graus histológicos de malignidade. Análise histomorfométrica foi empregada após técnica imuno-histoquímica para os anticorpos fator von-Willebrand e CD68. Uma diferença significante entre MDV e carcinomas bem e moderadamente diferenciados foi observada $(p<0,05)$. MAT estavam fortemente presentes em todos os tumores estudados e a DMIT não foi diferente entre os diferentes graus histológicos de malignidade do $\operatorname{CEC}(p=0,381)$. Correlação significante entre MDV e DMIT não foi observada $(p=0,870)$. Em conclusão, os resultados desse estudo sugerem a influência de MAT e angiogênese nos diferentes graus histológicos de malignidade do CEC. Entretanto, a ausência de correlação entre MDV e DMIT sugere que a angiogênese não depende do número de macrófagos presentes neste tipo de câncer, mas do fenótipo predominante. Outros estudos devem ser realizados a fim de contribuir para melhor compreensão da participação de MAT na angiogênese tumoral.

\section{Acknowledgments}

This study was supported by grants from the Conselho Nacional de Desenvolvimento Científico e Tecnológico (CNPq), Coordenação de Aperfeiçoamento de Pessoal de Nivel Superior (CAPES), Fundação de Amparo à Pesquisa do Estado do Rio de Janeiro (FAPERJ) and Fundação de Amparo à Pesquisa do Estado da Bahia (FAPESB). The authors are indebted to Dr. Leandro Miranda Alves for his technical support and to Dr. Abrahão Fontes Baptista for his statistical revision.

\section{References}

1. Shpitzer T, Chaimoff M, Gal R, Stern Y, Feinmesser R, Segal K. Tumor angiogenesis as a prognostic factor in early oral tongue cancer. Arch Otolaryngol Head Neck Surg 1996;122:865-868.

2. Ueno T, Toi M, Saji $H$, Muta M, Bando H, Kuroi K et al. Significance of macrophage chemoattractant protein-1 in macrophage recruitment, angiogenesis, and survival in human breast cancer. Clin Cancer Res 2000;6:3282-3289.

3. Mantovani $A$, Sica A. Macrophages, innate immunity and cancer: balance, tolerance, and diversity. Curr Opin Immunol 2010;22:231237.

4. Squadrito ML, Palma MD. Macrophage regulation of tumor angiogenesis: Implications for cancer therapy. Mol Aspects Med 2011;32:123-145.

5. Carmeliet P. Angiogenesis in life, disease and medicine. Nature 2005;438:932-936.

6. Polverini PJ, Leibovich SJ. Induction of neovascularization in vivo and endothelial proliferation in vitro by tumor-associated macrophages. Lab Invest 1984;51:635-642.

7. Utrera-Barillas D, Castro-Manrreza M, Castellanos E, GutiérrezRodríguez M, Arciniega Ruiz de Esparza 0, Garcia-Cebada J, et al.. The role of macrophages and mast cells in lymphangiogenesis and angiogenesis in cervical carcinogenesis. Exp Mol Pathol 2010;89:190196.

8. Christopoulos A, Ahn SM, Klein JD, Kim S. Biology of vascular endothelial growth factor and its receptors in head and neck cancer: Beyond angiogenesis. Head Neck 2010;33:1220-1229.

9. Mantovani A, Sozzani S, Locati M, Allavena P, Sica A. Macrophage polarization: tumor-associated macrophages as a paradigm for polarized M2 mononuclear phagocytes. Trends Immunol 2002;23:549-555.

10. Coussens LM, Werb Z. Inflammation and cancer. Nature 2002;420:860-867.

11 Li C, Shintani S, Terakado N, Nakashiro K, Hamakawa H. Infiltration of tumor-associated macrophages in human oral squamous cell carcinoma. Oncol Rep 2002;9:1219-1223.

12. Lu CF, Huang CS, Tjiu JW, Chiang CP. Infiltrating macrophage count: a significant predictor for the progression and prognosis of oral squamous cell carcinomas in Taiwan. Head Neck 2010;32:18-25.

13. Vilas Bôas DS, Takiya CM, Coelho-Sampaio TL, Monção-Ribeiro LC, Ramos EA, Cabral MG, et al.. Immunohistochemical detection of $\mathrm{Ki}-67$ is not associated with tumor-infiltrating macrophages and cyclooxygenase- 2 in oral squamous cell carcinoma. J Oral Pathol Med 2010;39:565-570.

14. Gale N, Pilch BZ, Sidransky D, Westra WH, Califano J. Tumours of the oral cavity and oropharynx (epithelial precursor lesions). In: Barnes L, Eveson JW, Reichart P, Sidransky D, editors. World Health Organization classification of tumours. Pathology and genetics of head and neck tumours. Lyon: International Agency for Research on Cancer; IARC Scientific Publications; 2005. p.177-179.

15. Högmo $A$, Kuylenstierna $R$, Lindholm J, Munck-Wikland $E$. Predictive value of malignancy grading systems, DNA content, p53, and angiogenesis for stage I tongue carcinomas. J Clin Pathol 1999;52:35-40.

16. Guttman D, Stern Y, Shpitzer T, Ulanovski D, Druzd T, Feinmesser R. Expression of MMP-9, TIMP-1, CD-34 and factor-8 as prognostic markers for squamous cell carcinoma of the tongue. Oral Oncol 2004;40:798-803.

17. Tan FL, Ginsburg D. What a polyclonal antibody sees in von Willebrand factor. Thromb Res 2008;121:519-526.

18. Weidner N, Semple JP, Welch WR, Folkman J. Tumor angiogenesis and metastasis--correlation in invasive breast carcinoma. N Engl J Med 1991;324:1-8.

19. Sharma B, Sriram G, Saraswathi TR, Sivapathasundharam B. Immunohistochemical evaluation of mast cells and angiogenesis in oral squamous cell carcinoma. Indian J Dent Res 2010;21:260-265.

20. El-Rouby DH. Association of macrophages with angiogenesis in oral verrucous and squamous cell carcinomas. J Oral Pathol Med 2010;39:559-564.

21. Nagata J, Kijima $H$, Hatanaka $H$, Tokunaga $T$, Takagi $A$, Mine $T$ et al.. Correlation between interleukin 10 and vascular endothelial 
growth factor expression in human esophageal cancer. Int J Mol Med 2002;10:169-172.

22. Fernández MM, Garcia-Rozado A, Parente PL. Is microvascular density an independent prognostic factor in squamous cell carcinoma of the tongue? Acta Otorrinolaringol Esp 2007;58:341-346.

23. Shigeoka $M$, Urakawa N, Nakamura T, Nishio M, Watajima T, Kuroda $D_{\text {, }}$ et al.. Tumor associated macrophage expressing CD204 is associated with tumor aggressiveness of esophageal squamous cell carcinoma. Cancer Sci 2013 [Epub ahead of print. DOI: 10.1111/cas.12188].

24. Komohara $Y$, Hasita H, Ohnishi K, Fujiwara Y, Suzu S, Eto M, et al. Macrophage infiltration and its prognostic relevance in clear cell renal cell carcinoma. Cancer Sci 2011;102:1424-1431.

Received July 27, 2012 Accepted April 5, 2013 